\title{
CONCEPTUAL TASKS OF SPATIAL STRUCTURING OF ECOLOGICAL AND ECONOMIC FUNDAMENTALS OF THE AGRICULTURAL SECTOR IN THE CONTEXT OF CROSS-BORDER COOPERATION
}

\author{
M. Vysochanska \\ $\mathrm{PhD}$ in Economics \\ Institute of Agroecology and Environmental Management of NAAS \\ (Kyiv, Ukraine) \\ e-mail: mariya vysochanska@ukr.net; \\ ORCID: https://orcid.org/0000-0003-2116-9991 \\ Ye. Hriaznykh \\ Researcher \\ Institute of Agroecology and Environmental Management of NAAS \\ (Kyiv, Ukraine) \\ e-mail: eli.d.hr.98@gmail.com; \\ ORCID: https://orcid.org/0000-0002-7701-8060
}

The article identifies the relevance and problems of cross-border cooperation in the context of the agricultural sector. Ukrainian-Polish cross-border cooperation in the agricultural sphere is studied, the positive aspects of cooperation are noted. Conceptual tasks of cross-border cooperation in the context of agrosphere are formed. The ecological and economic bases of cross-border cooperation in the agrosphere are considered, the forms of cross-border cooperation in relation to these principles are determined. The current state of cross-border cooperation in Ukraine is considered. Prospects for further cross-border cooperation are described.

Keywords: agro-sphere, cross-border cooperation, ecological and economic bases, agricultural activity, environment, agricultural products.

\section{INTRODUCTION}

Today, cross-border cooperation is becoming increasingly important, as the cooperation of border areas of neighboring countries contributes to the strengthening of political, social, environmental, economic and cultural ties, while at the same time forming a positive image of countries. In the context of international relations, there is a need to improve the old models of cross-border cooperation and increase their efficiency. Due to cross-border cooperation, globalization processes are taking place between countries in the context of the agricultural sector. In modern conditions, cross-border cooperation is an effective tool in strengthening the foreign economic activity of neighboring countries in the border areas. The formation of environmental and economic components of cross-border cooperation remains relevant for the coordination of cooperation within the cross-border territories of neighboring countries. Such a model ensures the effectiveness of the development of crossborder cooperation in the agricultural sector, and its implementation depends on the ability of countries to co-finance certain projects.

In the absence of specific approaches and mechanisms that coordinate the joint agricul- tural activities of the countries, trade in agricultural products, agricultural raw materials, cooperation in scientific and technical activities is restrained. To date, the system of ensuring the development of cross-border cooperation in the context of the agricultural sector has not been fully formed. Due to the well-established and coordinated cooperation of the border areas of neighboring countries, natural resource, as well as labor, material and financial potentials are actively used.

The goal of the work - to explore ecological and economic principles of the agrosphere in the context of cross-border cooperation, to determine the current state and prospects of development.

\section{ANALYSIS OF RECENT RESEARCH AND PUBLICATIONS}

In the domestic scientific literature, attention is paid to the theoretical foundations of cross-border cooperation in Ukraine in the works of such Ukrainian scientists as: Mikula, N.A. [1], Klyuchnik, A.V. and Strakhova, I.S. [6], Ustimenko, V.A. [7]. The study of cross-border cooperation on the example of the UkrainianPolish region in relation to the agricultural sec- 
tor is considered in the works of Tsiniska OB [3], Pavlik, I.E. [4], Kinakh, N.V. [5], Cymbalist, N.A. [9]. The conceptual principles of cross-border cooperation have been studied in the scientific works of Kish, E.B. [8], and cross-border cooperation in the development of the national economy - in the works of Chuchka, I.M. [2].

\section{MATERIALS AND RESEARCH METHODS}

Theoretical scientific methods, method of analysis and synthesis, analogy and modeling, as well as other general scientific and specific methods were used in the study of conceptual tasks of ecological and economic principles of the agricultural sector in the context of cross-border cooperation.

The theoretical component of the study of cross-border cooperation in the agricultural sector is considered based on Internet sources and information taken from domestic scientific resources.

\section{RESULTS AND DISCUSSION}

Today, cross-border cooperation of Ukraine plays an important role in improving the quality of life of the population of cross-border regions, ensuring the import and export of goods and services, as well as investing in agricultural activities. Cross-border cooperation stimulates the efficient use of local resources, confederations of neighboring states that jointly address issues related to the functioning of cross-border cooperation in agriculture, etc.

The basis of cross-border cooperation is the process of establishing ties and contractual relations in border areas in order to find solutions to common and identical problems, and the "philosophy of cross-border cooperation» is that two adjacent border regions cooperate in developing development plans and priorities, rather than working separately and then agreeing on development plans for individual activities. Cross-border cooperation is that all social groups and administrative bodies were involved in the dialogue in all spheres of life $[1$, p. 14].

The development of cross-border cooperation is ensured by taking into account social and environmental and economic factors. Such cooperation is a tool for the development of the agricultural sphere, solves the issue of development of adjacent regions of countries in relation to agricultural activities. Improving the living standards of the population in the border regions, the positive impact of integration processes, strengthening the activities of farms and agricultural complexes - all this is due to crossborder cooperation.
At the regulatory level, cross-border cooperation is provided by agreements on cross-border cooperation. Creation of new forms of cross-border cooperation (innovation structures, clusters, Euroregions) intensifies economic development, increased investment in border regions, rational use of natural resources of territories, etc.

Focusing on strengthening the activities of individual regions in cross-border cooperation has a negative impact on the formation of new ties, so the application of the experience of $\mathrm{Eu}-$ ropean countries will identify opportunities and increase the number of countries participating in cross-border cooperation. It is significant to increase the effectiveness of Ukraine's crossborder cooperation with neighboring countries - Moldova and Belarus. Due to the military aggression with Russia in eastern Ukraine, crossborder cooperation has gained more interregional cooperation.

In terms of ensuring the sustainable development of Ukraine, the establishment of its statehood is to strengthen the integration of the state economy into the world economic system by intensifying foreign economic activity and crossborder cooperation. It is the joint actions of local executive bodies of the country and territorial communities and relevant authorities of neighboring countries, aimed at deepening economic, social, scientific, technical, cultural and other relations, can ensure further socio-economic development of border areas [2, p. 144].

In identifying the problems associated with the development of the agricultural sector, it is possible to overcome the crisis, increase the efficiency of agricultural production, improve environmental protection. To ensure the sustainable development of the agricultural sector in the context of cross-border cooperation, it is necessary to optimize the use of natural resources and modernize economic activity in critical conditions. The search for new methods to address the crisis of social and environmental economic development of the agricultural sector is accompanied by the exchange of experience of networks in the form of local governments. Such networks form cross-border cooperation with the implementation of new projects to stimulate development, taking into account the social and environmental and economic situation, which have been implemented in other countries or regions. Cross-border cooperation of networks includes the following components: education, economy, public life, social assistance, transport infrastructure, culture, medicine, etc. There is an opportunity to involve research institutions, higher education institutions, consulting firms, public organizations, which, in turn, help to as- 
sess the effectiveness of cross-border cooperation networks.

The EU's experience shows that the process of socio-economic grouping promotes cross-border cooperation, which covers a wide range of activities in the fields of environment, culture, business, politics, as well as social and legal spheres. Significant benefits for cooperating cross-border regions should also be seen in the expansion of links and developments, better understanding between local governments, nongovernmental organizations, research centers and business partners on both sides of the border. The decisive result of such cooperation is the creation of favorable conditions for socio-economic modernization of the regions [2, p. 145].

Cooperation between border regions helps to eliminate the negative consequences arising from the peripheral regions of cross-border areas. In this case, cross-border cooperation implements the rules of international law, consolidation of society and economic development.

Ukraine has a unique geographical location and is endowed with geopolitical features - its simultaneous borders in the west with 4 EU member states (Poland, Slovakia, Hungary, Romania) [3, p. 68]. In this case, new opportunities and prospects arise in cross-border cooperation based on the creation of a new Association Agreement between Ukraine and the European Union. Such an agreement is the main tool for the implementation of integration processes, as well as a strategic direction in the implementation of public policy. Thanks to the Agreement, a free zone of trade in agricultural products in cross-border areas will be formed.

The main issue is that there is a need to establish contractual relations and close ties in cross-border areas. Adjacent borders have identical problems related to social, environmental, economic, cultural and even political and legislative factors. Border regions are engaged in establishing ties, increasing the effectiveness of cooperation, living standards of the region's population, economic development within the border, and so on. If we take for example the cross-border cooperation between Ukraine and Poland, then this is done by the border regions of Ukraine, such as Volyn, Zakarpattia and Lviv, and on the Polish side - Lublin and Podkarpackie.

Poland and Ukraine have similar trajectories of economic development. Both countries have brought agriculture into one of the main sectors of the economy, and therefore, consolidating the efforts of governments to cooperate in the agricultural sector can maximize the positive effect on filling the state budget and streng- thening their food security. Thus, at the theoretical and applied level it is necessary to establish the principles of cross-border cooperation between Ukraine and Poland, its directions, as well as to identify barriers that hinder the development of this form of interethnic cooperation. Another important task is to identify ways to intensify Ukrainian-Polish cooperation in the agricultural sector based on the results of the search for promising forms of Ukrainian-Polish cross-border cooperation. It should be emphasized that cross-border cooperation means a form of world economic integration of border areas $[4$, p. 64$]$.

In cross-border cooperation between Ukraine and Poland, Poland is one of the main partners in the context of the agricultural sector. States jointly solve problems related to the development of adjacent regions, ecological and economic situation, intensification of agricultural activities, etc. Ukraine and Poland have identical traditions, geoeconomic interests, and historical heritage.

Ukraine has all the opportunities and incentives to initiate approaches to cross-border cooperation in the form of the advantage of the geographical location of borders at the crossroads, which, in turn, streamlines efficient logistics systems for delivering agricultural products to consumers in the cross-border region. Currently, more attention is paid to organic food, which, incidentally, is highly valued in the European Union.

One of the main goals of cross-border cooperation in the agricultural sector of Ukraine with Poland is to create favorable conditions for the development of border agricultural areas. The current stage of strengthening market relations in the agricultural sector of the economy has necessitated the development of agro-industrial integration on a fundamentally new economic basis. Cross-border cooperation between Ukraine and Poland in the agricultural sector is implemented on the basis of jointly developed programs of trade, economic and scientific and technical cooperation. The main motives for the development of integration processes in agricultural production are the unity of the technological cycle of production (production - processing - sale) and the synergistic effect that arises as a result of economies of scale and the combination of complementary resources [4, p. 65].

Cross-border cooperation in the context of the agricultural sector is aimed at efficient and rational use of natural resources within crossborder regions, providing the population of the region with food, normalization of agricultural products on the market, raising the rural population of cross-border areas. 
The current state of cooperation between Ukraine and Poland can be described both positively and problematically. There are many positive aspects of such cooperation:

- introduction of new technologies, which increases the investment attractiveness of the territory for both domestic and foreign investors;

- improvement and maximum use of the tourist potential of the region;

- improving the quality and accessibility of socio-economic infrastructure, in particular in the field of transport, energy, logistics systems, transport safety and water supply;

- ensuring and improving environmental protection;

- improving the efficiency of border infrastructure and procedures, as well as improving border security;

- social, scientific, educational and cultural integration of the border area [5, p. 105].

The main direction in cross-border Ukrainian-Polish cooperation is the formation of a wellestablished agricultural policy and a common market for agricultural products with free border trade zones. This creates opportunities for joint investment, development of mechanisms for optimizing the investment climate, taxation of agricultural activities of enterprises. It is also important to develop measures to support the innovative activities of agricultural complexes. All this makes it possible to expand the export of Ukrainian agricultural products, in turn, increasing revenues to local budgets, increasing the number of jobs, stabilizing the segment of Ukrainian agricultural products of plant and animal origin in international markets.

Under the Agreement on Cross-Border Cooperation, each state contributes to the development of cross-border cooperation, namely: ensures the prosperity of construction in the region, agricultural production, environmental protection, development of education, culture and historical heritage, etc. Cross-border cooperation has a number of tasks that are necessary to ensure the development of the agro-industrial complex in the cross-border region (Fig. 1).

In the prism of cross-border cooperation is the development of the agricultural sector through mechanisms that regulate the market of agro-industrial products, protect plants and animals, food production, assistance between states or enterprises in border areas, breeding and processing of animal products, exchange of agricultural experience, acceleration of agricultural production, etc.

Cross-border cooperation is an important tool in solving the problems of the regions in

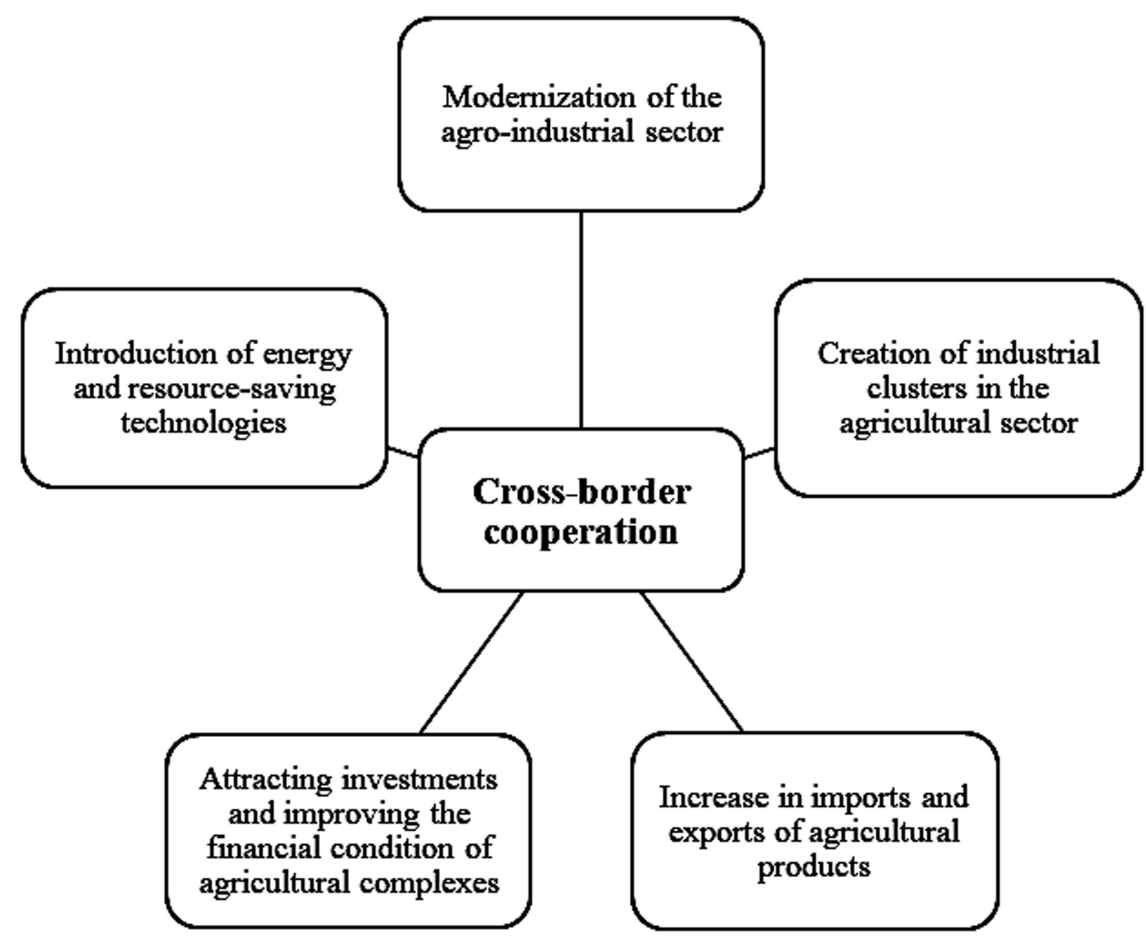

Fig. 1. Conceptual tasks of cross-border cooperation in the context of the agrosphere. Source: created by the authors on the basis of [6]. 
Ecological and economic principles of the agricultural sector on cross-border cooperation

\begin{tabular}{|c|c|}
\hline Ecological & Economic \\
\hline $\begin{array}{l}\text { Ensuring the protection of the natural } \\
\text { environment, restoration and improvement } \\
\text { of its condition. } \\
\text { ntroduction of environmentally friendly } \\
\text { production. } \\
\text { Reduction of waste disposal in the environment. } \\
\text { Responsible conservation of biological diversity } \\
\text { within cross-border areas. } \\
\text { Protection against soil erosion. } \\
\text { Rational land use, etc. }\end{array}$ & $\begin{array}{l}\text { Development of rural industry. } \\
\text { Expansion of service areas in agriculture } \\
\text { (for example, service of agricultural machinery). } \\
\text { Increasing imports and exports of agricultural } \\
\text { products in the cross-border region. } \\
\text { Production of environmentally friendly } \\
\text { electricity at the green tariff, etc. }\end{array}$ \\
\hline
\end{tabular}

Source: developed by the authors on the basis of [7].

the agricultural sector, which is based on institutional foundations, spatial approach, which in the long run has a long-term and sustainable effect. Establishing links between regions of cross-border cooperation will allow each country to accelerate its own development of territories. Table 1 can consider the environmental and economic principles of cross-border cooperation in the agricultural sector.

The ecological principles are based on the common interests and efforts of the border areas of the states to overcome international and regional problems related to the natural environment. Cross-border cooperation of states plans and implements special programs (projects) to obtain information on the state of the environmental sphere, research, implementation of environmental management to share experiences in the context of environmental crises, training of environmental specialists and specialists if necessary.

Basing cross-border cooperation on economic grounds allows to develop and implement joint programs (projects) for economic and business cooperation in the agricultural sector, exchange information between countries on the economic situation in the agricultural sector, determine investment needs and implement investment flows in agricultural complexes.

The pragmatic essence of cross-border cooperation is the maximum involvement of external factors for the comprehensive socio-economic development of border regions in order to prevent the threat of turning them into backward peripheral provinces of their states. This is how the levels of regional development of border and internal territories of the countries are equalized [8, p. 69].

Cross-border cooperation is due to legal and constitutional field of states. Cooperation between cross-border territories should not con- tradict the state interests of the countries. Development is aimed at strengthening the harmonization of border regions with the participation of international integration processes.

Analysis of the current state of Ukrainian-Polish cooperation in the agricultural sector of the economy indicates a fairly low intensity. Numerous cross-border cooperation programs and strategies involving Poland and Ukraine emphasize the need for cooperation in the field of agriculture to ensure its sustainable development and reduce the harmful impact on the environment. However, there are no specific joint Ukrainian-Polish programs of measures and projects in this area, and cooperation between economic entities in the field of agriculture has not become sufficiently widespread, despite the fact that «some Polish farmers have already found partners on the Ukrainian side and are developing joint business, for example, in the production of poultry meat, vegetables and fruits and in the cultivation of pigs» [9, p. 243].

Today, the formation of international standards for cross-border cooperation in Ukraine with clearly defined areas of implementation of profitable projects is an important issue. Determining environmental and economic factors in the regions is of great importance in the process of globalization of Ukraine's relations with other states. Local governments, which have interregional and cross-border legal relations, also play a key role.

\section{CONCLUSIONS}

Cross-border cooperation in the agricultural sector strengthens social, environmental, economic, scientific and technological ties between countries within cross-border regions. Problems are the limitation of information on the potential of the agricultural sphere of cross-border regions, scant funding, imperfection of the 
Conceptual tasks of spatial structuring of ecological and economic fundamentals

of the agricultural sector in the context of cross-border cooperation

system approach to the development of crossborder cooperation in the agricultural sector. The foundations of cross-border cooperation are the application of international experience in agricultural production and cooperation in it, access to new foreign markets for agricultural products, strengthening imports and exports, joining new countries to cross-border cooperation and attracting new investment.

The new agreements on cross-border cooperation provide an opportunity to unite the efforts of states to quickly overcome crises and achieve the set goals in ensuring the development of the agricultural sector in the regions. At the same time, special attention should be paid to the effective protection of the natural environment and the rational use of natural resources, as well as the search for new non-traditional methods of production and sale of quality agricultural products.
In Ukraine, there is an intensification of cross-border relations with other countries, especially with the countries of the European Union. Development and improvement of ecological and economic bases is the most developed form of cross-border cooperation. Peripheral and industrially developed territories contribute to the functioning of Euroregions in Ukraine.

Effective development of cross-border regions is the main catalyst for the successful development of Ukraine's integration processes. This, in turn, allows to stimulate cross-border cooperation, intensifying trade in agricultural products within cross-border regions, while equalizing the quality of life on both sides of the borders of neighboring countries. There is also a convergence of rural areas in cross-border regions, which increases per capita income, profitability of agricultural activities in the regions.

\section{REFERENCES}

1. Mikula, N.A. (2011). Transkordonne spivrobitnytstvo: posibnyk [Cross-border cooperation: textbook]. Kyiv: vydavnytstvo «Kramar» [in Ukrainian].

2. Chuchka, I.M. (2014). Vplyv transkordonnoho spivrobitnytstva na rozvytok natsionalnoi ekonomiky [The impact of cross-border cooperation on the development of the national economy]. Aktualni problemy ekonomiky - Current economic problems, 5 (155), 143-151 [in Ukrainian].

3. Tsisinska, O.B. (2015). Osoblyvosti sotsialno-ekonomichnoho rozvytku ukrainsko-polskoho transkordonnoho rehionu [Features of socio-economic development of the Ukrainian-Polish cross-border region]. Sotsialno-ekonomichni problemy suchasnoho periodu Ukrainy, 6 (116), 68-73 [in Ukrainian].

4. Pavlik, I.Y. (2017). Transkordonne spivrobitnytstvo Ukrainy i Polshchi v ahrarnii sferi: problemy ta perspektyvy [Cross-border cooperation between Ukraine and Poland in the agricultural sector: problems and prospects]. Ekonomichnyi analiz - Economic analysis, 3, vol. 27, 62-70 [in Ukrainian].

5. Kinakh, N.V. (2017). Osoblyvosti funktsionuvannia silskykh terytorii ukraino-polskoho transkordonnoho rehionu [Features of the functioning of rural areas of the Ukrainian-Polish cross-border region]. Mizhnarodnyi naukovyi zhurnal Internauka - International scientific journal «Internauka», 3 (25), vol. 2, 104-107 [in Ukrainian].

6. Kliuchnyk, A.V., \& Strakhova, I.S. (2015). Rozvytok mizhnarodnoho mizhrehionalnoho spivrobitnytstva $\mathrm{v}$ ahrarnomu sektori mykolaivskoi oblasti [Development of international interregional cooperation in the agricultural sector of the Nikolaev area]. Naukovyi visnyk Khersonskoho derzhavnoho universytetu. Ekonomichni nauky - Scientific Bulletin of Kherson State University. Economic sciences, 12, part 3, 123-126 [in Ukrainian].

7. Ustymenko, V.A. (2020). Transkordonne spivrobitnytstvo: pravovi osnovy ta uspishni praktyky: posibnyk [Cross-border cooperation: legal framework and best practices: textbook]. Kyiv [in Ukrainian].

8. Kish, Ye.B. (2017). Transkordonne spivrobitnytstvo u KhKhI stolitti: kontseptualnyi pidkhid [Transborder cooperation in XXI century: conceptual issues]. Rehionalni studii - Regional studios, 11, 67-73 [in Ukrainian].

9. Tsymbalista, N.A. (2014). Ukrainsko-polske transkordonne spivrobitnytstvo v ahrarnii sferi u konteksti yevropeiskoi intehratsii: suchasnyi stan ta perspektyvy rozvytku [Ukrainian-Polish cross-border cooperation in the agricultural sector in the context of European integration: current status and development prospects]. Sotsialno-ekonomichni problemy suchasnoho periodu Ukrainy, 2(106), 240-247 [in Ukrainian].

\section{КОНЦЕПТУАЛЬНІ ЗАВДАННЯ ПРОСТОРОВОГО СТРУКТУРУВАННЯ ЕКОЛОГО-ЕКОНОМІЧНИХ ЗАСАД АГРАРНОГО СЕКТОРУ В КОНТЕКСТІ ТРАНСКОРДОННОГО СПІВРОБІТНИЦТВА}

М.Я. Височанська кандидат економічних наук Інститут агроекології і природокористування НААН (м. Київ, Україна) e-mail: mariya vysochanska@ukr.net; ORCID: https://orcid.org/0000-0003-2116-9991 


\section{Є.Д. Грязних \\ науковий співробітник \\ Інститут агроекології і природокористування НААН (м. Київ, Україна) e-mail: eli.d.hr.98@gmail.com; \\ ORCID: https: / /orcid.org/0000-0002-7701-8060}

У статті визначено актуальність та проблеми транскордонного співробітництва в контексті аграрного сектору. Досліджено українсъко-польсъке транскордонне співробітництво в аграрній сфбері, зазначені позитивні сторони співпраці. Сбормовано концептуальні завдання транскордонної співпраці в контексті агросбери. Розглянуто еколого-економічні основи транскордонного співробітниитва в агросфері, визначені борми здійснення транскордонної співпрачі шодо ицх засад. Розглянуто нинішній стан транскордонної співпраці в Україні. Охарактеризовано перспективи подальиого транскордонного співробітниитва.

Ключові слова: агросбера, транскордонна співпраия, екологічні та економічні основи, сілъсъкогосподарсъка діяльність, навколишнє природнє середовище, агропродукиія.

\section{ЛITEPATУРА}

1. Мікула Н.А. Транскордонне співробітництво: посібник. Київ: видавництво «Крамар», 2011. 259 с.

2. Чучка I.M. Вплив транскордонного співробітництва на розвиток національної економіки. Економіка та управління національним господарством. Ажтуалъні проблеми економіки. 2014. № 5 (155). C. $143-151$.

3. Цісінська О.Б. Особливості соціально-економічного розвитку українсько-польського транскордонного регіону. Соціально-економічні проблеми сучасного періоду України. 2015. Випуск 6 (116). C. $68-73$.

4. Павлік I.Є. Транскордонне співробітництво України і Польщі в аграрній сорері: проблеми та перспективи. Економічний аналіз. 2017. Том 27. № 3. С. 62-70.

5. Кінах Н.В. Особливості функціонування сільських територій україно-польського транскордонного регіону. Міжнародний науковий журнал “Інтернаука». Економічні науки. 2017. Том 2 . № 3 (25). C. $104-107$.

6. Ключник А.В., Страхова I.С. Розвиток міжнародного міжрегіонального співробітництва в аграрному секторі Миколаївської області. Науковий вісник Херсонсъкого державного університету. Економічні науки. 2015. Випуск 12. Частина 3. С. 123-126.

7. Устименко В.А. Транскордонне співробітництво: правові основи та успішні практики: посібник. Київ, 2020. 152 c.

8. Кіш Є.Б. Транскордонне співробітництво у XXI столітті: концептуальний підхід. Регіоналъні студї. 2017. Випуск 11. С. 67-73.

9. Цимбаліста Н.А. Українсько-польське транскордонне співробітництво в аграрній сфері у контексті європейської інтеграції: сучасний стан та перспективи розвитку. Соціально-екологічні проблеми сучасного періоду України. 2014. Вип. 2 (106). С. 240-247.

\section{ВІДОМОСТІ ПРО АВТОРІВ}

Височанська Марія Ярославівна, кандидат економічних наук, заступник директора з наукової роботи та інноваційного розвитку, Інститут агроекології і природокористування НАAН (вул. Метрологічна, 12, м. Київ, 03143, Україна; e-mail: mariya_vysochanska@ukr.net; ORCID: https://orcid.org/0000-0003-2116-9991)

Грязних Слизавета Денисівна, науковий співробітник, Інститут агроекології і природокористування НААН (вул. Метрологічна, 12, м. Київ, 03143, Україна; e-mail: eli.d.hr.98@gmail.com; ORCID: https://orcid.org/0000-0002-7701-8060) 